\title{
Dry Matter Production, Nutrient Cycled and Removed, and Soil Fertility Changes in Yam-Based Cropping Systems with Herbaceous Legumes in the Guinea-Sudan Zone of Benin
}

\author{
Raphiou Maliki, ${ }^{1}$ Brice Sinsin, ${ }^{2}$ Anne Floquet, ${ }^{3}$ Denis Cornet, ${ }^{4}$ \\ Eric Malezieux, ${ }^{5}$ and Philippe Vernier ${ }^{4}$ \\ ${ }^{1}$ Institut National des Recherches Agricoles du Bénin (INRAB), P.O. Box 2128, Calavi, Benin \\ ${ }^{2}$ Faculté des Sciences Agronomiques de l'Université d'Abomey-Calavi (FSA/UAC), P.O. Box 01-526, Cotonou, Benin \\ ${ }^{3}$ Centre Béninois pour l'Environnement et le Développement Economique et Social (CEBEDES), P.O. Box 02-331, Cotonou, Benin \\ ${ }^{4}$ Centre de Coopération Internationale en Recherche Agronomique pour le Développement (CIRAD), \\ 34398 Montpellier Cedex 5, France \\ ${ }^{5}$ Centre de Coopération Internationale en Recherche Agronomique pour le Développement (CIRAD), UPR Hortsys, \\ 34398 Montpellier Cedex 5, France \\ Correspondence should be addressed to Raphiou Maliki; malikird@yahoo.fr
}

Received 13 December 2015; Accepted 22 May 2016

Academic Editor: Zeng-Yei Hseu

Copyright (C) 2016 Raphiou Maliki et al. This is an open access article distributed under the Creative Commons Attribution License, which permits unrestricted use, distribution, and reproduction in any medium, provided the original work is properly cited.

Traditional yam-based cropping systems (shifting cultivation, slash-and-burn, and short fallow) often result in deforestation and soil nutrient depletion. The objective of this study was to determine the impact of yam-based systems with herbaceous legumes on dry matter (DM) production (tubers, shoots), nutrients removed and recycled, and the soil fertility changes. We compared smallholders' traditional systems (1-year fallow of Andropogon gayanus-yam rotation, maize-yam rotation) with yam-based systems integrated herbaceous legumes (Aeschynomene histrix/maize intercropping-yam rotation, Mucuna pruriens/maize intercroppingyam rotation). The experiment was conducted during the 2002 and 2004 cropping seasons with 32 farmers, eight in each site. For each of them, a randomized complete block design with four treatments and four replicates was carried out using a partial nested model with five factors: Year, Replicate, Farmer, Site, and Treatment. Analysis of variance (ANOVA) using the general linear model (GLM) procedure was applied to the dry matter (DM) production (tubers, shoots), nutrient contribution to the systems, and soil properties at depths $0-10$ and 10-20 cm. DM removed and recycled, total $\mathrm{N}, \mathrm{P}$, and $\mathrm{K}$ recycled or removed, and soil chemical properties (SOM, N, P, K, and $\mathrm{pH}$ water) were significantly improved on yam-based systems with legumes in comparison with traditional systems.

\section{Introduction}

One of the most serious problems of farming system is the excessive reductions of agricultural productivity resulting from major degradation of soil fertility. In 1990 Edouard Saouma wrote that the most serious problem of African countries in the future can be that of land degradation [1]. To understand how and why lands become degraded, one needs some knowledge of the physical environment, population, cultivation history, and farming systems $[2,3]$.
Current yam-based cropping systems, which involve shifting cultivation, slash-and-burn, or short fallow, often result in deforestation and soil nutrient depletion [4]. As long as population pressure was low, the cropping phase was short compared to the fallow period. Three or four years of cultivation followed by ten years or more of fallow, for example, allows the accumulation of easily degradable organic matter to regenerate soil fertility $[5,6]$. Where population increases, available land per inhabitant is reduced and fallow periods shorten. Traditional long-fallow shifting cultivation 
can no longer continue in most of humid Sub-Saharan Africa. Increasing population densities are posing a serious threat to natural resources and agricultural production. Farmers' response to higher food demand has been either an increase in cultivated area or a reduction of fallow period. The minimum fallow duration to maintain crop production was estimated at 12 years [7]. Fallow periods in most of the humid zone of West and Central Africa are actually between 2 and 5 years [8], reinforcing the need to seek alternative food production systems [7].

Yam (Dioscorea spp.) is a tuber crop widely cultivated in the humid and subhumid lowland regions of West Africa and the Caribbean [9]. More than $90 \%$ of the worldwide production (40 Mt fresh tubers/year) is produced in West Africa [10]. Yam is grown in traditional cropping systems as the first crop after land clearance, yielding about $10 \mathrm{t}$ of fresh tuber/ha/year [11], but when the soil fertility is high, it can easily reach 25-30 t/ha in farm fields [12] with Dioscorea cayenensis-rotundata varieties. In Benin nowadays, farmers hardly have the possibility to rely on long duration fallow and yam is being cultivated in 1- or 2-year herbaceous fallow or maize rotation systems with manual incorporation of residue into the soil $[13,14]$. Smallholder farmers removed important quantities of nutrient from their soil without applying a sufficient quantity of manure or fertilizer to replenish the soil [15].

Yam cultivation in West Africa is now confronted with the scarcity of fertile soil available for clearing [4]. In Benin nowadays, farmers hardly have the possibility to rely on long duration fallow and yam is being cultivated in 1- or 2year herbaceous fallow-yam or maize-yam rotation systems with manual incorporation of residue into the soil [13, 14]. Smallholder farmers removed important quantities of nutrient from their soil without applying a sufficient quantity of manure or fertilizer to replenish the soil [15].

The decline in yam yields under continuous cultivation has led to the largely accepted conclusion that yam requires a high level of natural soil fertility (organic matter and nutrient) [16]. Since the demand for yam keeps increasing due to the continued population growth, reserves of arable land are diminishing, and fallow duration is decreasing. It is becoming necessary to sustainably increase yam productivity in sedentary cropping systems [16]. There is a dire need therefore to assess in farmers' conditions the economic performance of sustainable cultivation techniques. Ongoing soil degradation could be reduced by the adoption of new farming techniques such as improved fallows of herbaceous legumes $[17,18]$.

Studies on improved fallow practices are generally grainoriented (cereals, such as maize), whereas very little has been done on root and tuber crops, especially yam. Comparative studies are lacking that assess the effects of yambased technologies with herbaceous legumes intercrops and short fallows on yam production and soil properties in the savannah transition agroecological zone of Benin. We compared in a perennial experiment for 4 years, with 2-year rotations, smallholder farmers' traditional rotations maizeyam or 1-year Andropogon gayanus fallow-yam with rotations intercropped Aeschynomene histrix with maize-yam or intercropped Mucuna pruriens with maize-yam. The objective of

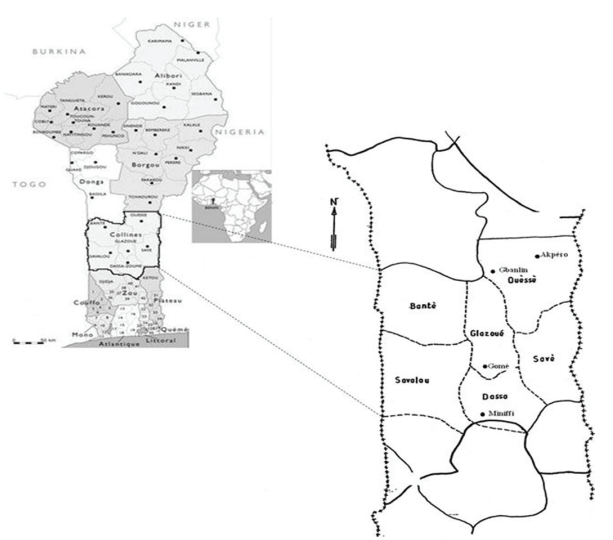

FIGURE 1: Study area location in the savannah transitional agroecological zone of Benin.

this study was to determine the impact of yam-based systems with herbaceous legumes on dry matter (DM) production (tubers and shoots), nutrients removed and recycled, and the soil fertility changes.

\section{Materials and Methods}

2.1. Study Sites. The study was carried out in the GuineaSudan transition zone of Benin (centre of Benin) in four sites: Miniffi (District of Dassa-Zoumè), Gomè (Glazoué), Akpéro, and Gbanlin (Ouessè) with latitudes $7^{\circ} 45^{\prime}$ and $8^{\circ} 40^{\prime}$ north and longitudes $2^{\circ} 20^{\prime}$ and $2^{\circ} 35^{\prime}$ east (Figure 1 ).

The climate is tropical transitional Guinea-Sudan with a rainfall distribution gradient from bimodal (Southern Benin) to monomodal (Northern Benin). The average annual rainfall during the study period was $1052 \mathrm{~mm}$ (2002), $1386 \mathrm{~mm}$ (2003), $983 \mathrm{~mm}$ (2004), and $797 \mathrm{~mm}$ (2005). The rainfall regime in the study area is variable and unequal distribution (i.e., number of rainy days per month) varies from one site to another. The 2002 and 2003 cropping seasons were wet and had better rainfall distribution with an average annual precipitation of $1200 \mathrm{~mm}$, whereas 2004 and 2005 were dry (890 $\mathrm{mm})$ with relatively low rainfall distribution.

Most of the soils are tropical ferruginous soils [19], originally from Precambrian crystalline rocks (granite and gneiss), and classified as plinthosols (Gbanlin and Akpéro) and luvisols (Miniffi and Gomè) [20] (Table 1). Miniffi, Akpéro, and Gbanlin are located on a plateau while Gomè is on lowland. Akpéro is close to forest while Gbanlin, Miniffi, and Gomè are far. There is a rising gradient of fertility from the continuous cropping system on degraded soils towards the forests. This degradation is related to soil organic matter decrease, which leads to nutrient depletion (nutrients removed in the crop harvest, leaching, and erosion). Vegetation is a degraded woody savannah type. Maize, yam, cassava, and groundnut are annual cropping systems and the cash crops are cotton and soybean. Mineral fertilizer application appears to be essential. Smallholder farmers use fertilizers on maize on depleted soils depending on cash and inputs availability. Cotton is not mixed cropping, but pure crop in rotation with other crops (maize or sorghum). 


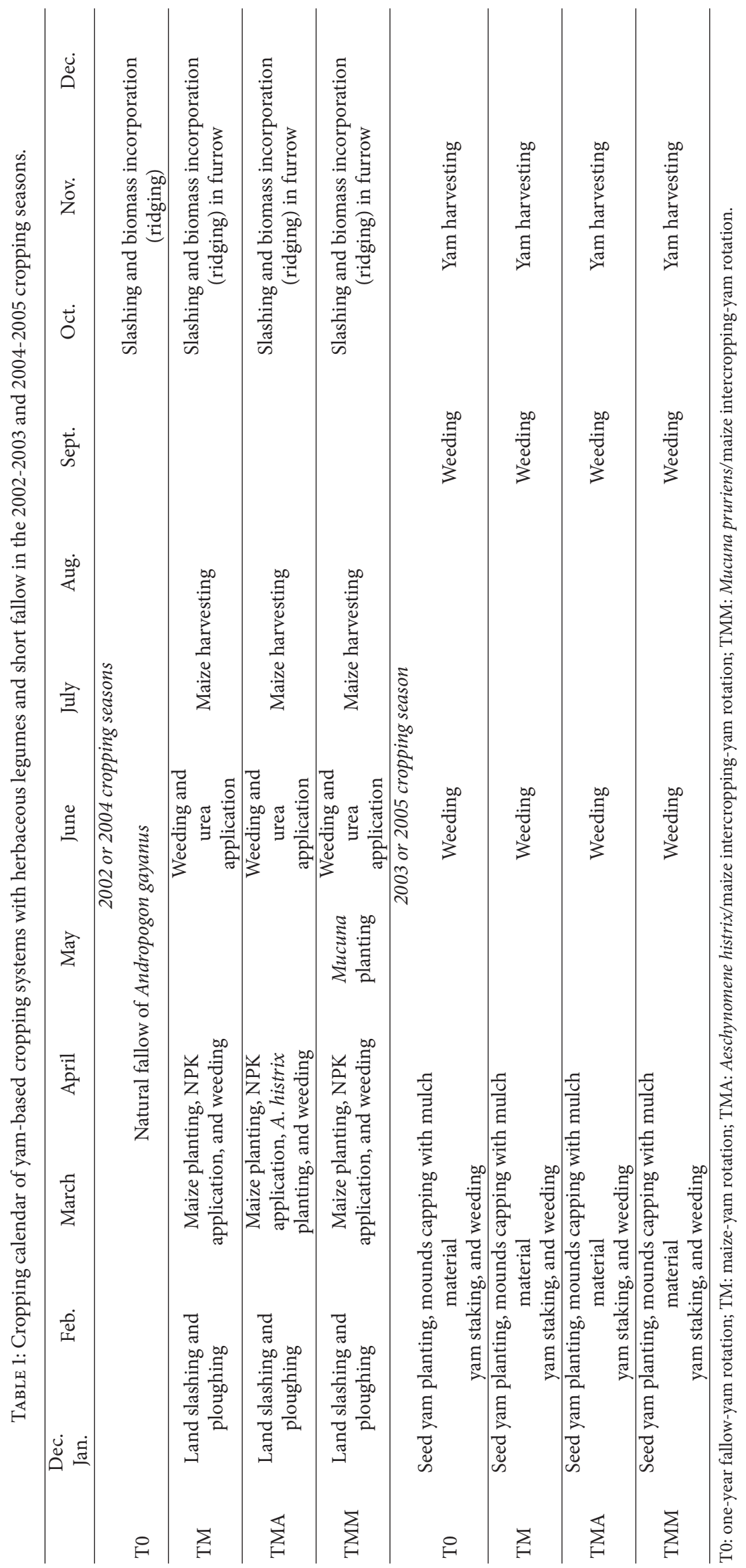


2.2. On-Farm Experiment. The concept of the experiment was to produce residue biomass followed by planting yam in rotation cropping systems. A previous cover crop (fallows or intercropped maize/legume) was designed to provide organic matter for the following main crop (yam) (Table 1).

Smallholders carried out two-year rotations experiment of yam-based cropping systems repeated twice (2002-2005) on-farm with single-harvest late maturing variety of yam "Kokoro" (Dioscorea rotundata). This is one of the most cultivated species in the study area due to its good aptitude for conservation and processing into dried tubers (the so-called chips), flour, and starchy paste (locally called amala) [21]. We conducted the experiment with 32 farmers, eight in each site (Miniffi, Gomè, Akpéro, and Gbanlin). For each of them, we used a randomized block design with four replications and four levels of treatment. Plot size was $10 \mathrm{~m} \times 10 \mathrm{~m}$ (total of $1600 \mathrm{~m}^{2}$ per farm). The four treatments were as follows:

(i) T0 (Control 1). T0 is one-year fallow-yam rotation, which is a common practice in the area. A natural fallow of Andropogon gayanus grass was grown in the first year.

(ii) TM (Control 2). TM indicates maize-yam rotation, which is also a common practice in the area. Maize was planted (spacing $80 \mathrm{~cm} \times 40 \mathrm{~cm}$ ) in April of the first year.

With recurring drought stress exacerbated by highly variable and unpredictable rains in the study area, some farmers grow a second crop, which often fails. This corroborates the great interest of the maize/leguminous crop when no second crop is planned.

(iii) TMA. TMA is intercropped Aeschynomene histrix with maize-yam rotation: maize was planted in April of the first year. A. histrix seeds $\left(7 \mathrm{~kg} \mathrm{ha}^{-1}\right)$ were mixed with dry sand ( $3 / 4$ sand and $1 / 4$ seeds) and sown two weeks after the maize.

(iv) TMM. TMM is intercropped Mucuna pruriens with maize-yam rotation: maize was planted in April of the first year. $M$. pruriens seeds $\left(25 \mathrm{~kg} \mathrm{ha}^{-1}\right)$ were sown at spacing $80 \mathrm{~cm} \times 40 \mathrm{~cm}$ in May six weeks after the maize.

On treatments TM, TMA, and TMM, $100 \mathrm{kgha}^{-1}$ NPK fertilizer $(14 \% \mathrm{~N}, 10 \% \mathrm{P}$, and $11.7 \% \mathrm{~K})$ was applied to maize in April and $50 \mathrm{~kg} \mathrm{ha}^{-1}$ urea $(46 \% \mathrm{~N})$ in June. The maize was harvested in July. The grainless $M$. pruriens and $A$. histrix crops were mowed 140 and 180 days, respectively, after planting. Organic matter was incorporated in moulds and left on the surface as mulch in October and then yam was planted directly on these moulds, without mineral fertilization.

2.3. Data Collection. Composite soil samples were collected in each field before the beginning of the experiment along plot transects at soil depths of $0-10 \mathrm{~cm}$ and $10-20 \mathrm{~cm}$ (32 farm fields $\times 2$ depths $=64$ samples) in order to determine soil characteristics. At the end of 2005 before yam harvesting, composite soil samples were collected at the same depths in
TABLE 2: Quantity of biomass ( $\left.\mathrm{tha}^{-1}\right)$ dry matter and nutrients contents ( $\%$ and $\mathrm{kg} \mathrm{ha}^{-1}$ ) applied in each plot in the 2002 cropping seasons, four village sites (Miniffi, Gomè, Gbanlin, and Akpéro), Benin.

\begin{tabular}{lccccccc}
\hline Site/treatment & $\begin{array}{c}\mathrm{DM} \\
\mathrm{tha}^{-1}\end{array}$ & $\begin{array}{c}\mathrm{N} \\
\%\end{array}$ & $\begin{array}{c}\mathrm{P} \\
\%\end{array}$ & $\begin{array}{c}\mathrm{K} \\
\%\end{array}$ & $\begin{array}{c}\mathrm{N} \\
\mathrm{kg} \mathrm{ha}^{-1}\end{array}$ & $\begin{array}{c}\mathrm{P} \\
\mathrm{kg} \mathrm{ha}^{-1}\end{array}$ & $\begin{array}{c}\mathrm{K} \\
\mathrm{kg} \mathrm{ha}^{-1}\end{array}$ \\
\hline $\begin{array}{c}\text { Akpéro } \\
\text { T0 }\end{array}$ & 4.1 & 1.7 & 0.2 & 0.5 & 68.4 & 7.8 & 21.2 \\
TM & 3.5 & 1.3 & 0.1 & 0.5 & 45.3 & 5.2 & 17.4 \\
TMA & 9.6 & 1.3 & 0.1 & 0.5 & 125.9 & 14.1 & 47.6 \\
TMM & 10.2 & 1.7 & 0.2 & 0.5 & 177.8 & 20.2 & 53.9 \\
\hline Gbanlin & & & & & & & \\
T0 & 4.0 & 1.0 & 0.2 & 0.5 & 42.2 & 6.0 & 20.7 \\
TM & 3.5 & 2.3 & 0.2 & 0.6 & 78.5 & 8.1 & 22.1 \\
TMA & 9.1 & 1.5 & 0.1 & 0.6 & 132.3 & 9.3 & 56.6 \\
TMM & 9.5 & 1.9 & 0.2 & 0.6 & 180.4 & 14.3 & 61.1 \\
\hline Miniff & & & & & & & \\
T0 & 4.3 & 0.9 & 0.2 & 0.6 & 41.1 & 6.7 & 27.6 \\
TM & 3.7 & 1.9 & 0.1 & 0.6 & 70.7 & 4.8 & 22.1 \\
TMA & 9.3 & 1.2 & 0.3 & 0.6 & 114.8 & 26.1 & 59.7 \\
TMM & 9.9 & 2.4 & 0.1 & 0.6 & 239.6 & 14.9 & 63.2 \\
\hline Gomè & & & & & & & \\
T0 & 4.0 & 0.9 & 0.1 & 0.5 & 36.4 & 5.0 & 19.6 \\
TM & 3.5 & 2.5 & 0.1 & 0.6 & 86.9 & 2.6 & 22.2 \\
TMA & 9.0 & 1.2 & 0.1 & 0.4 & 104.9 & 5.4 & 34.2 \\
TMM & 9.8 & 1.6 & 0.1 & 0.6 & 160.1 & 6.7 & 60.1 \\
\hline
\end{tabular}

the moulds along plot transects ( 32 farm fields $\times 4$ treatments $\times 2$ depths $=256$ samples).

Prior to ridging, in four $1 \mathrm{~m}^{2}$ quadrats within each plot the aboveground biomass of herbaceous legumes and fallow was collected in October 2002 and 2004. The biomass samples were dried at $60^{\circ} \mathrm{C}$ until constant weight and then dry weight was determined. At maturity, maize grain and stover were harvested per row on each plot and dry matter (DM) determined. DM of yam tubers and shoots was estimated on each plot in December 2003 and 2005 (Tables 2 and 3).

2.4. Soil and Plant Nutrients Content. The nutrients contents of the soil samples were performed in the Laboratory of Soil Sciences, Water and Environment (LSSEE) of INRAB (Benin National Research Institute). The plant nutrient content was estimated according to the biomass amount.

Soil and plant macronutrients content ( N, P, and $\mathrm{K}$ ) were analyzed. Nitrogen $(\mathrm{N})$ content was analyzed using the Kjeldahl method [22], available phosphorus with Bray 1 method [23], potassium with the FAO method [24, 25], organic carbon with the Walkley and Black method [26], and soil fractionation with Robinson method [27] and $\mathrm{pH}$ $\left(\mathrm{H}_{2} \mathrm{O}\right)$ (using a glass electrode in $1: 2.5 \mathrm{v} / \mathrm{v}$ soil solution). Only yam tuber and maize grain were removed, and all other plants parts were recycled (A. gayanus, maize stover, yam shoot, $A$. histrix, and $M$. pruriens). Yam or M. pruriens shoot included leaves. Nutrient removed or recycled was calculated as a summation of nutrient concentration time dry matter of 
TABLE 3: Quantity of biomass $\left(\mathrm{tha}^{-1}\right)$ dry matter and nutrients contents ( $\%$ and $\mathrm{kg} \mathrm{ha}^{-1}$ ) applied in each plot in the 2004 cropping seasons, four village sites (Miniffi, Gomè, Gbanlin, and Akpéro), Benin.

\begin{tabular}{lccccccc}
\hline Site/treatment & $\begin{array}{c}\mathrm{DM} \\
\mathrm{tha}^{-1}\end{array}$ & $\begin{array}{c}\mathrm{N} \\
\%\end{array}$ & $\begin{array}{c}\mathrm{P} \\
\%\end{array}$ & $\begin{array}{c}\mathrm{K} \\
\%\end{array}$ & $\begin{array}{c}\mathrm{N} \\
\mathrm{kg} \mathrm{ha}^{-1}\end{array}$ & $\begin{array}{c}\mathrm{P} \\
\mathrm{kg} \mathrm{ha}^{-1}\end{array}$ & $\begin{array}{c}\mathrm{K} \\
\mathrm{kg} \mathrm{ha}^{-1}\end{array}$ \\
\hline Akpéro & & & & & & & \\
T0 & 4.3 & 1.7 & 0.2 & 0.5 & 72.7 & 8.3 & 22.4 \\
TM & 3.7 & 1.3 & 0.1 & 0.5 & 47.2 & 5.4 & 18.1 \\
TMA & 9.3 & 1.3 & 0.1 & 0.5 & 121.5 & 13.7 & 46.0 \\
TMM & 10.2 & 1.7 & 0.2 & 0.5 & 179.7 & 20.4 & 54.4 \\
\hline Gbanlin & & & & & & & \\
T0 & 4.1 & 1.0 & 0.2 & 0.5 & 42.7 & 6.1 & 21.0 \\
TM & 3.5 & 2.3 & 0.2 & 0.6 & 78.7 & 8.1 & 22.2 \\
TMA & 9.0 & 1.5 & 0.1 & 0.6 & 131.0 & 9.2 & 56.1 \\
TMM & 9.6 & 1.9 & 0.2 & 0.6 & 182.0 & 14.4 & 61.6 \\
\hline Miniffi & & & & & & & \\
T0 & 4.0 & 0.9 & 0.2 & 0.6 & 38.2 & 6.2 & 25.5 \\
TM & 3.4 & 1.9 & 0.1 & 0.6 & 65.0 & 4.4 & 20.3 \\
TMA & 9.4 & 1.2 & 0.3 & 0.6 & 115.4 & 26.3 & 60.1 \\
TMM & 10.0 & 2.4 & 0.1 & 0.6 & 240.2 & 14.9 & 63.3 \\
\hline Gomè & & & & & & & \\
T0 & 4.0 & 0.9 & 0.1 & 0.5 & 36.3 & 5.0 & 19.5 \\
TM & 3.5 & 2.5 & 0.1 & 0.6 & 86.5 & 2.6 & 22.2 \\
TMA & 9.3 & 1.2 & 0.1 & 0.4 & 107.9 & 5.6 & 35.2 \\
TMM & 9.6 & 1.6 & 0.1 & 0.6 & 157.3 & 6.6 & 59.1 \\
\hline
\end{tabular}

the respective plant parts. Dry matter removed or recycled was calculated as a summation of dry matter of the respective plant parts.

2.5. Analyses of Variance to Test the Effect of Site, Year, and Treatment on Yam Yield. Analysis of variance (ANOVA) using the general linear model (GLM) procedure [28] was applied to the DM production (tubers and shoots), nutrient contribution to the systems, and soil properties at depths $0-10$ and $10-20 \mathrm{~cm}$. The experiment was conducted with 32 farmers, eight in each site. For each of them, a randomized complete block design with four treatments and four replicates was carried out using a partial nested model with five factors: Year, Replicate, Farmer, Site, and Treatment. The random factors were "Year" and "Replicate" and "Farmer." Farmer was considered as nested within "Site" and "Replicate" as nested within "Farmer." The fixed factors were "Treatment" and "Site." Sites were considered as fixed based on certain criteria such as landscape (lowland and plateau), soil type, and initial soil fertility. Yield values were logarithmically transformed to normalize the data and to stabilize population variance. The GLM was computed to assess the interactions between the factors involved. Least square means and standard error were also computed for factor levels, and the Newman and Keuls test was applied for differences between treatments. Significance was regarded at $P \leq 0.05$.

\section{Results}

3.1. Initial Soil Characteristics. The relevant general soil physical and chemical characteristics before are presented in Table 4.

Site physical characteristics such as soil texture (sand) were relatively high $(74.778 \%-88.79 \%)$ followed by silt $(5.55 \%-17.36 \%)$ and clay $(5.66 \%-7.861 \%)$ with the lowest content. The soils had a neutral reaction, with $\mathrm{pH}(\mathrm{H} 2 \mathrm{O})$ ranging from 6.3 to 6.8 .

The initial soil fertility status of different sites was low. Soil organic matter (SOM) contents were low in all fields, ranging from $0.93 \%$ to $2.258 \%$, and the $\mathrm{C}: \mathrm{N}$ ratio ranged from 8.69 to 11.70. Available $\mathrm{P}$ levels were very low and varied from 3.012 to $20.125 \mathrm{mg} / \mathrm{kg}$-soil. Soil $\mathrm{N}$ concentration ranged from $0.056 \%$ to $0.112 \%$. N, P, and SOM contents were significantly higher in $0-10 \mathrm{~cm}$ than in 10-20 cm depth, except at Gbanlin site for $\mathrm{N}$ and SOM. Gomè site showed, for both soil depths, the lowest values of carbon (C\%), N\%, P (mg/kg-soil), and organic matter (\%), whereas Akpéro had the highest values.

3.2. Dry Matter Production and Nutrient Contribution to the Systems. In the 2002 and 2004 cropping seasons, the highest biomass dry matter (DM) amount recycled was recorded on TMM (Table 5).

The ANOVA partial nested model shows that yam yield DM differed significantly depending on the factor Treatment $(P<0.001)$. The factors Site and Year were not significant for yam yields DM. But Replicate $(P<0.001)$, Treatment $\times$ Farmer $(P<0.01)$, and Year $\times$ Farmer interactions $(P<$ 0.001) were significant (Table 6).

Dry matter $\left(\mathrm{tha}^{-1}\right)$ of yam tubers removed and yam shoots recycled, $\mathrm{N}, \mathrm{P}$, and $\mathrm{K}$ content $\left(\mathrm{kg} \mathrm{ha}^{-1}\right)$ dry matter of plant parts removed in the crop harvest, and those returned to the soil in yam-based cropping systems were significantly higher in TMA and TMM than in T0 and TM during both cropping seasons (Tables 7 and 8).

Therefore, total plant $\mathrm{N}, \mathrm{P}$, and $\mathrm{K}\left(\mathrm{kg} \mathrm{ha}^{-1}\right)$ dry matter removed in the crop harvest and those returned to the soil in yam-based cropping systems were significantly higher in TMA and TMM than in T0 and TM during both cropping seasons (Table 9).

3.3. Effects of Treatments on Soil Characteristics. Afterwards soil characteristics at the end of the experiment globally showed relatively low clay, silt, and relatively high sand concentration on different sites under different treatments (T0, TM, TMA, and TMM) in comparison with initial soil characteristics at the beginning of the experiment. Soil organic matter concentration was improved at 10-20 cm depth particularly in Miniffi (1.247\%, 1.176\%, 1.326\%, and $1.409 \%)$ on T0, TM, TMA, and TMM, respectively, and Gomè (1.010\%, $0.959 \%, 1.046 \%$, and $1.126 \%)$. Globally, soil $\mathrm{N}$ and P concentrations were improved on different sites on treatments TMA and TMM in $0-10 \mathrm{~cm}$ or $10-20 \mathrm{~cm}$ depth (Tables $10(\mathrm{a})-10(\mathrm{~d})$ ).

The end of study soil analysis showed soil chemical properties (SOM\%, N\%, P (mg/kg-soil), $\mathrm{K}^{+} \mathrm{cmol} \mathrm{kg}^{-1}$, and $\mathrm{pH}$ water) significantly higher in TMA and TMM than in traditional systems T0 and TM $(P<0.001)$. Soil clay contents 
TABLE 4: Initial soil characteristics at the beginning of the experiment at $0-10$ and $10-20 \mathrm{~cm}$ layers in four village sites (Miniffi, Gomè, Gbanlin, and Akpéro) with 32 farmers, Benin.

\begin{tabular}{|c|c|c|c|c|c|c|c|c|}
\hline \multirow{3}{*}{ Depth $(\mathrm{cm})$} & \multicolumn{2}{|c|}{ Akpéro } & \multicolumn{2}{|c|}{ Gbanlin } & \multicolumn{2}{|c|}{ Miniffi } & \multicolumn{2}{|c|}{ Gomè } \\
\hline & $0-10$ & $10-20$ & $0-10$ & $10-20$ & $0-10$ & $10-20$ & $0-10$ & $10-20$ \\
\hline & \multicolumn{2}{|c|}{ "Plinthosols" } & \multicolumn{2}{|c|}{ "Plinthosols" } & \multicolumn{2}{|c|}{ "Luvisols ferriques" } & \multicolumn{2}{|c|}{ "Luvisols ferriques" } \\
\hline Clay\% & 6.58 & 7.281 & 5.788 & 5.66 & 6.758 & 6.51 & 6.828 & 7.861 \\
\hline Silt $\%$ & 11.66 & 11.798 & 5.808 & 5.55 & 6.828 & 7.081 & 16.071 & 17.36 \\
\hline Sand\% & 81.76 & 80.920 & 88.402 & 88.79 & 86.412 & 86.408 & 77.10 & 74.778 \\
\hline $\mathrm{C} \%$ & 1.31 & 1.050 & 0.69 & 0.788 & 0.80 & 0.64 & 0.65 & 0.54 \\
\hline N\% & 0.112 & 0.092 & 0.059 & 0.081 & 0.081 & 0.056 & 0.073 & 0.062 \\
\hline $\mathrm{C} / \mathrm{N}$ & 11.70 & 11.43 & 11.70 & 9.68 & 9.83 & 11.43 & 8.90 & 8.69 \\
\hline OM\% & 2.25 & 1.81 & 1.19 & 1.36 & 1.37 & 1.10 & 1.12 & 0.93 \\
\hline $\mathrm{PH}$ & 6.7 & 6.7 & 6.6 & 6.3 & 6.7 & 6.8 & 6.6 & 6.6 \\
\hline Bray P & 20.125 & 14.875 & 7.00 & 4.00 & 11.00 & 3.012 & 7.987 & 4.00 \\
\hline
\end{tabular}

C\%: soil carbon concentration; N\%: soil nitrogen concentration; OM\% (=1.72 $\times \mathrm{C} \%)$ : soil organic matter content; $\mathrm{C} / \mathrm{N}$ : index of biodegradability or ratio of soil carbon to nitrogen; Bray P $\left(\mathrm{mg} \mathrm{kg}^{-1}\right)$ : soil phosphorus.

TABLE 5: Dry matter $\left(\mathrm{tha}^{-1}\right)$ of plant parts returned to the soil significantly increased according to four cropping systems (A. histrix/maize intercropping-yam rotation; $M$. pruriens/maize intercropping-yam rotation; 1-year fallow of Andropogon gayanusyam rotation; maize-yam rotation) during the 2002 and 2004 cropping seasons in four villages in Benin.

\begin{tabular}{lcc}
\hline Cropping system & $\begin{array}{c}\text { Cropping season 2002 } \\
\text { DM }\left(\mathrm{t} \mathrm{ha}^{-1}\right)\end{array}$ & $\begin{array}{c}\text { Cropping season 2004 } \\
\text { DM }\left(\mathrm{t} \mathrm{ha}^{-1}\right)\end{array}$ \\
\hline T0 & $4.1^{\mathrm{c}}$ & $3.9^{\mathrm{c}}$ \\
TM & $3.5^{\mathrm{d}}$ & $3.2^{\mathrm{d}}$ \\
TMA & $9.2^{\mathrm{b}}$ & $8.3^{\mathrm{b}}$ \\
TMM & $9.7^{\mathrm{a}}$ & $8.8^{\mathrm{a}}$
\end{tabular}

Means with the same letter within row are not significantly different $(P>$ $0.05)$.

T0 (control 1): one-year fallow-yam rotation; TM (control 2): maize-yam rotation; TMA: A. histrix/maize intercropping-yam rotation; TMM: $M$. pruriens/maize intercropping-yam rotation; DM: dry matter.

were significantly higher in TMA, TMM, and T0 than in TM $(P<0.001)$. No significant difference was observed for silt and sand concentrations for different treatments (Table 10(e)).

\section{Discussion}

4.1. Dry Matter and Nutrients Recycled in Yam-Based Cropping Systems. The highest biomass dry matter (DM) amount recycled was recorded on Mucuna/maize intercropping (TMM). Mucuna grows rapidly and DM production can reach 10 tha $^{-1}[2,17,29]$. In fact, Mucuna creeps and climbs maize straw in pattern crop allowing the lianas staking. Therefore, Mucuna large leaves profit from solar radiations improving the photosynthetic activity and the plant productivity. Mucuna reaches the physiological maturity (flowering time) between 180 and 240 days after grains planting in the study area in comparison with Aeschynomene (200-306 days) [30, 31].
DM of yam shoots recycled on TMA and TMM were significantly higher in 2005 (dry year) than in 2003 (humid year). The chemical fertilizers applied and the above biomass $\mathrm{DM}$ of intercropping maize and herbaceous legume recycled and accumulated in 2002, 2003, and 2004 could have resulted in a combined beneficial effect of water, nutrient use, and plant growth in 2005. DM amounts of $M$. pruriens, A. histrix, and maize stover recycled were higher in 20022003 (humid year) than in 2004-2005 (dry year). In fact, plant yields and agronomic productivity were constrained by recurring drought stress exacerbated by highly variable and unpredictable rains. $M$. pruriens stover showed the highest DM amount followed by A. histrix whatever the year and this could reach $10 \mathrm{tha}^{-1}$ [18] because $M$. Pruriens, compared with A. histrix, grows more rapidly and close.

The nutrient $(\mathrm{N}, \mathrm{P}$, and $\mathrm{K})$ levels removed or recycled fit the DM production (tubers and shoots) and then varied according to treatment and cropping season.

4.2. Impact of Yam-Based Cropping Systems with Herbaceous Legumes on Soil Properties. Most of the soils as mentioned above are tropical ferruginous soils, originally from Precambrian crystalline rocks (granite and gneiss) and classified as plinthosols (Gbanlin and Akpéro) and luvisols (Miniffi and Gomè). Miniffi and Akpéro are located on a plateau (well-drained soils) while Gomè is on lowland (more poorly drained soils). Gbanlin is located on an undulating plateau with concretions. Soil chemical analysis showed that the soil was deficient in N, P, and $\mathrm{K}$ and soil organic matter (SOM). This could be due to the mining agriculture and also a consequence of the mechanical destruction of the soil structure during the ridging for yam crop. In fact yam is a demanding crop in terms of organic matter and nutrients. Research [32] reported that yam yielding about $30 \mathrm{t}$ of fresh tuber ha ${ }^{-1}$ removes $120 \mathrm{~N} \mathrm{~kg} \mathrm{ha}^{-1}, 5.1 \mathrm{P} \mathrm{kg} \mathrm{ha}^{-1}$, and $111 \mathrm{~K} \mathrm{~kg} \mathrm{t}^{-1}$. When land is used too intensively, the SOM is rapidly reduced in the unstable fraction. In the short and medium term, this reduction leads to a decrease in soil biological activity 
TABLE 6: ANOVA, partial nested model of the effect of the four treatments on logarithmic transformed values of dry matter yields of "Kokoro" yam (Dioscorea rotundata) (2002-2003 and 2004-2005, 4 sites, 32 farmers, Benin).

\begin{tabular}{|c|c|c|c|c|c|}
\hline Source & $\mathrm{DF}$ & Adj. SS & Adj. MS & $F$ & $P$ \\
\hline Site & 3 & 0.4258 & 0.1419 & $* *$ & \\
\hline Farmer (Site) & 28 & 3.4833 & 0.1244 & 0.18 & 1.000 \\
\hline Replicate (Site) & 96 & 42.3111 & 3.5259 & 27 & 0.000 \\
\hline Year & 1 & 0.0002 & 0.0002 & 0.01 & 0.943 \\
\hline Treatment & 3 & 224.0376 & 74.6792 & 5344.06 & 0.000 \\
\hline Site $\times$ Treatment & 9 & 0.0291 & 0.0032 & 0.11 & 0.999 \\
\hline Treatment $\times$ Farmer (Site far) & 84 & 2.2389 & 0.0267 & 1.62 & 0.001 \\
\hline Year $\times$ Farmer $($ Site $)$ & 28 & 6.933 & 0.2476 & 15.02 & 0.000 \\
\hline Year $\times$ Treatment & 3 & 0.0114 & 0.0038 & 0.2 & 0.892 \\
\hline Year $\times$ Site & 3 & 0.141 & 0.047 & 0.19 & 0.904 \\
\hline Year $\times$ Site $\times$ Treatment & 9 & 0.1685 & 0.0187 & 1.14 & 0.334 \\
\hline Error & 756 & 12.4598 & 0.0165 & & \\
\hline Adjusted $R$-square (\%) & & & 94.24 & & \\
\hline
\end{tabular}

DF: degree of freedom; Adj. SS: adjusted sums of squares; Adj. MS: adjusted mean squares; $F$ : Fisher's test; $P$ : Fisher's probability test.

** Denominator of $F$-test is zero.

TABLE 7: Dry matter $\left(\mathrm{tha}^{-1}\right)$ of yam tubers removed and yam shoots recycled in the 2002-2003 and 2004-2005 cropping seasons in four villages in Benin.

\begin{tabular}{|c|c|c|c|c|c|c|c|c|c|c|}
\hline & \multicolumn{5}{|c|}{ 2002-2003 cropping seasons } & \multicolumn{5}{|c|}{ 2004-2005 cropping seasons } \\
\hline & T0 & TM & TMA & TMM & LSD & T0 & $\mathrm{TM}$ & TMA & TMM & LSD \\
\hline \multicolumn{11}{|c|}{ Yam DM removed $\left(\right.$ tha $\left.^{-1}\right)$} \\
\hline DM removed & $5.09^{\mathrm{b}}$ & $3.83^{\mathrm{c}}$ & $7.20^{\mathrm{a}}$ & $7.33^{\mathrm{a}}$ & 0.51 & $4.34^{\mathrm{b}}$ & $3.02^{\mathrm{c}}$ & $8.00^{\mathrm{a}}$ & $8.02^{\mathrm{a}}$ & 0.55 \\
\hline \multicolumn{11}{|c|}{ Yam shoots DM recycled $\left(\right.$ tha $\left.^{-1}\right)$} \\
\hline Yam shoots & $1.27^{\mathrm{b}}$ & $0.96^{\mathrm{c}}$ & $1.80^{\mathrm{a}}$ & $1.83^{\mathrm{a}}$ & 0.13 & $1.09^{\mathrm{b}}$ & $0.76^{\mathrm{c}}$ & $2.00^{\mathrm{a}}$ & $2.00^{\mathrm{a}}$ & 0.14 \\
\hline
\end{tabular}

Means with the same letter within row are not significantly different $(P>0.05)$.

DM: dry matter; LSD: least square difference at $5 \%$.

T0 (control 1): one-year fallow-yam rotation; TM (control 2): maize-yam rotation; TMA: A. histrix/maize intercropping-yam rotation; TMM: M. pruriens/maize intercropping-yam rotation.

and, then, contributes to soil degradation and depletion [33]. Many studies report that soil organic matter (SOM) decreases in cultivated soils [33]. This decrease is linked to the depth of the cultivated soil layer and is probably exacerbated in yambased cropping systems.

Nitrogen is the most deficient component of these soils grown with low organic matter content. Total nitrogen deficiency of these soils lies in the fact that nitrogen is the only major nutrient that does not exist in the bedrock. Further, the transfer of atmospheric nitrogen to the soil by biological and chemical process is slow. Losses of nitrogen in these soils are common because of the high volatility and solubility of this nutrient. Nitrogen is generated by the breakdown of inherent organic matter and needs to be supplemented with other sources of organic materials or mineral fertilizer. Many studies focusing on these elements conclude that there is an indisputable need to correct the lack of $\mathrm{N}$ and $\mathrm{P}$ in the soil in Africa [2, 6].

It is possible to reduce or stop ongoing soil degradation and the decrease in yield with such rotations including improved short fallows or intercropping with herbaceous legumes. The use of legumes improves levels of concentration of the soil parameters. The improvement of the clay concentration at the end of the perennial experiment could be due to the process of the composite soil samples collected on the ridges resulting from the brewing of the soil deep layer relatively rich in clay and the soil horizon surface after ridging. Indeed, ridging allows increasing the volume of the soil deep layer and contributes to the incorporation of organic residues into the soil.

Significant differences in total SOM and nutrients increase with treatments TMA and TMM in comparison with T0 and TM could be due to the faster decomposition of fermentable green manure (herbaceous legumes) with low humification coefficient (5\%) added to the moderate decomposition of lignified maize stover on relatively degraded soils [34]. Our observations are in agreement with those of [35] who reported that cropping systems and organic manures have the most influence on the SOM. Rotations with $M$. pruriens and $A$. histrix represented a source of easily available $\mathrm{N}, \mathrm{P}$, and $\mathrm{K}$ for the yam crop which could be related to their faster decomposition and nutrient release, compared with the slower release of nutrients by poorer quality materials such as maize stover and A. gayanus grass. In Ghana, studying the 
TABLE 8: Nitrogen, phosphorus, and potassium content $\left(\mathrm{kg} \mathrm{ha}^{-1}\right)$ dry matter of plant parts removed in the crop harvest and those returned to the soil in yam-based cropping systems (2002-2003 and 2004-2005 cropping seasons, four cropping system treatments, four village sites, 32 farmers, Benin).

\begin{tabular}{|c|c|c|c|c|c|c|c|c|c|c|c|c|c|}
\hline & & \multicolumn{6}{|c|}{ 2002-2003 cropping seasons } & \multicolumn{6}{|c|}{ 2004-2005 cropping seasons } \\
\hline & & T0 & $\mathrm{TM}$ & TMA & TMM & LSD & SD & T0 & TM & TMA & TMM & LSD & SD \\
\hline \multicolumn{14}{|c|}{ Plant nutrients removed $\left(\mathrm{kg} \mathrm{ha}^{-1}\right)$} \\
\hline \multirow{4}{*}{ Yam tubers } & $\mathrm{N}$ & $19.35^{\mathrm{b}}$ & $14.57^{\mathrm{c}}$ & $27.37^{\mathrm{a}}$ & $27.84^{\mathrm{a}}$ & 1.95 & 2.98 & $16.49^{\mathrm{b}}$ & $11.48^{\mathrm{c}}$ & $30.41^{\mathrm{a}}$ & $30.47^{\mathrm{a}}$ & 2.08 & 3.18 \\
\hline & $\mathrm{P}$ & $1.99^{\mathrm{b}}$ & $1.49^{\mathrm{c}}$ & $2.81^{\mathrm{a}}$ & $2.86^{\mathrm{a}}$ & 0.20 & 0.31 & $1.69^{\mathrm{b}}$ & $1.18^{\mathrm{c}}$ & $3.12^{\mathrm{a}}$ & $3.13^{\mathrm{a}}$ & 0.21 & 0.33 \\
\hline & K & $21.39^{\mathrm{b}}$ & $16.10^{\mathrm{c}}$ & $30.25^{\mathrm{a}}$ & $30.77^{\mathrm{a}}$ & 2.16 & 3.30 & $18.23^{\mathrm{b}}$ & $12.70^{\mathrm{c}}$ & $33.61^{\mathrm{a}}$ & $33.68^{\mathrm{a}}$ & 2.30 & 3.52 \\
\hline & $\mathrm{N}$ & $0.00^{\mathrm{b}}$ & $34.88^{\mathrm{a}}$ & $34.43^{\mathrm{a}}$ & $33.38^{\mathrm{a}}$ & 2.27 & 3.47 & $0.00^{\mathrm{c}}$ & $31.52^{\mathrm{a}}$ & $27.68^{\mathrm{b}}$ & $26.71^{b}$ & 2.03 & 3.11 \\
\hline \multirow[t]{2}{*}{ Maize grains } & $\mathrm{P}$ & $0.00^{\mathrm{b}}$ & $5.30^{\mathrm{a}}$ & $5.24^{\mathrm{a}}$ & $5.08^{\mathrm{a}}$ & 0.35 & 0.53 & $0.00^{\mathrm{c}}$ & $4.79^{\mathrm{a}}$ & $4.21^{\mathrm{b}}$ & $4.06^{\mathrm{b}}$ & 0.31 & 0.47 \\
\hline & $\mathrm{K}$ & $0.00^{\mathrm{b}}$ & $4.34^{\mathrm{a}}$ & $4.28^{\mathrm{a}}$ & $4.15^{\mathrm{a}}$ & 0.28 & 0.43 & $0.00^{\mathrm{c}}$ & $3.92^{\mathrm{a}}$ & $3.44^{\mathrm{b}}$ & $3.32^{\mathrm{b}}$ & 0.25 & 0.39 \\
\hline \multicolumn{14}{|c|}{ Plant nutrients recycled $\left(\mathrm{kg} \mathrm{ha}^{-1}\right)$} \\
\hline \multirow{4}{*}{ Yam shoots } & $\mathrm{N}$ & $14.01^{\mathrm{b}}$ & $10.54^{\mathrm{c}}$ & $19.81^{\mathrm{a}}$ & $20.15^{\mathrm{a}}$ & 1.41 & 2.16 & $11.72^{\mathrm{b}}$ & $8.16^{\mathrm{c}}$ & $21.60^{\mathrm{a}}$ & $21.65^{\mathrm{a}}$ & 1.48 & 2.26 \\
\hline & $\mathrm{P}$ & $1.91^{\mathrm{b}}$ & $1.44^{\mathrm{c}}$ & $2.70^{\mathrm{a}}$ & $2.75^{\mathrm{a}}$ & 0.19 & 0.29 & $1.30^{\mathrm{b}}$ & $0.91^{\mathrm{c}}$ & $2.40^{\mathrm{a}}$ & $2.41^{\mathrm{a}}$ & 0.16 & 0.25 \\
\hline & K & $17.57^{\mathrm{b}}$ & $13.22^{c}$ & $24.85^{\mathrm{a}}$ & $25.28^{\mathrm{a}}$ & 1.77 & 2.71 & $14.65^{\mathrm{b}}$ & $10.20^{\mathrm{c}}$ & $27.01^{\mathrm{a}}$ & $27.06^{\mathrm{a}}$ & 1.85 & 2.83 \\
\hline & $\mathrm{N}$ & $47.63^{\mathrm{a}}$ & $0.00^{\mathrm{b}}$ & $0.00^{\mathrm{b}}$ & $0.00^{\mathrm{b}}$ & 3.86 & 5.91 & $47.03^{\mathrm{a}}$ & $0.00^{\mathrm{b}}$ & $0.00^{\mathrm{b}}$ & $0.00^{\mathrm{b}}$ & 4.22 & 6.46 \\
\hline \multirow[t]{3}{*}{ Fallow stover } & $\mathrm{P}$ & $5.26^{\mathrm{a}}$ & $0.00^{\mathrm{b}}$ & $0.00^{\mathrm{b}}$ & $0.00^{\mathrm{b}}$ & 1.23 & 1.89 & $5.09^{\mathrm{a}}$ & $0.00^{\mathrm{b}}$ & $0.00^{\mathrm{b}}$ & $0.00^{\mathrm{b}}$ & 1.27 & 1.94 \\
\hline & K & $19.90^{\mathrm{a}}$ & $0.00^{\mathrm{b}}$ & $0.00^{\mathrm{b}}$ & $0.00^{\mathrm{b}}$ & 2.16 & 3.30 & $19.49^{\mathrm{a}}$ & $0.00^{\mathrm{b}}$ & $0.00^{\mathrm{b}}$ & $0.00^{\mathrm{b}}$ & 1.98 & 3.03 \\
\hline & $\mathrm{N}$ & $0.00^{\mathrm{b}}$ & $31.87^{\mathrm{a}}$ & $31.43^{\mathrm{a}}$ & $30.47^{\mathrm{a}}$ & 2.45 & 3.75 & $0.00^{c}$ & $33.45^{\mathrm{a}}$ & $29.35^{\mathrm{b}}$ & $28.28^{\mathrm{b}}$ & 2.60 & 3.97 \\
\hline \multirow[t]{3}{*}{ Maize stover } & $\mathrm{P}$ & $0.00^{\mathrm{b}}$ & $4.56^{\mathrm{a}}$ & $4.51^{\mathrm{a}}$ & $4.37^{\mathrm{a}}$ & 0.39 & 0.60 & $0.00^{c}$ & $4.65^{\mathrm{a}}$ & $4.08^{\mathrm{b}}$ & $3.95^{\mathrm{b}}$ & 0.45 & 0.68 \\
\hline & K & $0.00^{c}$ & $17.48^{\mathrm{ab}}$ & $18.57^{\mathrm{a}}$ & $16.76^{\mathrm{b}}$ & 1.86 & 2.84 & $0.00^{\mathrm{c}}$ & $17.42^{\mathrm{a}}$ & $15.30^{\mathrm{b}}$ & $14.80^{\mathrm{b}}$ & 1.42 & 2.17 \\
\hline & $\mathrm{N}$ & $0.00^{\mathrm{b}}$ & $0.00^{\mathrm{b}}$ & $115.93^{\mathrm{a}}$ & $0.00^{\mathrm{b}}$ & 6.63 & 10.14 & $0.00^{\mathrm{b}}$ & $0.00^{\mathrm{b}}$ & $107.70^{\mathrm{a}}$ & $0.00^{\mathrm{b}}$ & 9.34 & 14.28 \\
\hline \multirow[t]{3}{*}{ Aeschy. stover } & $\mathrm{P}$ & $0.00^{\mathrm{b}}$ & $0.00^{\mathrm{b}}$ & $8.15^{\mathrm{a}}$ & $0.00^{\mathrm{b}}$ & 0.97 & 1.49 & $0.00^{\mathrm{b}}$ & $0.00^{\mathrm{b}}$ & $8.76^{\mathrm{a}}$ & $0.00^{\mathrm{b}}$ & 0.69 & 1.05 \\
\hline & K & $0.00^{\mathrm{b}}$ & $0.00^{\mathrm{b}}$ & $36.25^{\mathrm{a}}$ & $0.00^{\mathrm{b}}$ & 1.33 & 2.03 & $0.00^{\mathrm{b}}$ & $0.00^{\mathrm{b}}$ & $34.53^{\mathrm{a}}$ & $0.00^{\mathrm{b}}$ & 1.70 & 2.60 \\
\hline & $\mathrm{N}$ & $0.00^{\mathrm{b}}$ & $0.00^{\mathrm{b}}$ & $0.00^{\mathrm{b}}$ & $138.92^{\mathrm{a}}$ & 6.53 & 9.99 & $0.00^{\mathrm{b}}$ & $0.00^{\mathrm{b}}$ & $0.00^{\mathrm{b}}$ & $133.25^{\mathrm{a}}$ & 5.28 & 8.07 \\
\hline \multirow[t]{2}{*}{ Mucuna stover } & $\mathrm{P}$ & $0.00^{\mathrm{b}}$ & $0.00^{\mathrm{b}}$ & $0.00^{\mathrm{b}}$ & $11.40^{\mathrm{a}}$ & 1.81 & 2.77 & $0.00^{\mathrm{b}}$ & $0.00^{\mathrm{b}}$ & $0.00^{\mathrm{b}}$ & $11.11^{\mathrm{a}}$ & 1.61 & 2.46 \\
\hline & K & $0.00^{\mathrm{b}}$ & $0.00^{\mathrm{b}}$ & $0.00^{\mathrm{b}}$ & $39.73^{\mathrm{a}}$ & 1.51 & 2.31 & $0.00^{\mathrm{b}}$ & $0.00^{\mathrm{b}}$ & $0.00^{\mathrm{b}}$ & $39.68^{\mathrm{a}}$ & 1.78 & 2.72 \\
\hline
\end{tabular}

Means with the same letter within row are not significantly different $(P>0.05)$.

T0 (control 1): one-year fallow-yam rotation; TM (control 2): maize-yam rotation; TMA: A. histrix/maize intercropping-yam rotation; TMM: M. pruriens/maize intercropping-yam rotation; SD: standard deviation; LSD: least square difference at $5 \%$.

TABLE 9: Total plant nitrogen, phosphorus, and potassium $\left(\mathrm{kg} \mathrm{ha}^{-1}\right)$ dry matter removed in the crop harvest and those returned to the soil in yam-based cropping systems (2002-2003 and 2004-2005 cropping seasons, four cropping system treatments, four village sites, 32 farmers, Benin).

\begin{tabular}{lccccccccccccc}
\hline & & \multicolumn{4}{c}{ 2002-2003 cropping seasons } & \multicolumn{4}{c}{ 2004-2005 cropping seasons } \\
& & T0 & TM & TMA & TMM & LSD & SD & T0 & TM & TMA & TMM & LSD & SD \\
\hline Total nutrients removal & $\mathrm{N}$ & $19.35^{\mathrm{c}}$ & $49.44^{\mathrm{b}}$ & $61.80^{\mathrm{a}}$ & $61.22^{\mathrm{a}}$ & 2.91 & 4.46 & $16.49^{\mathrm{c}}$ & $43.01^{\mathrm{b}}$ & $58.09^{\mathrm{a}}$ & $57.18^{\mathrm{a}}$ & 2.90 & 4.44 \\
through harvest & $\mathrm{P}$ & $1.99^{\mathrm{c}}$ & $6.80^{\mathrm{b}}$ & $8.05^{\mathrm{a}}$ & $7.93^{\mathrm{a}}$ & 0.39 & 0.60 & $1.69^{\mathrm{c}}$ & $5.97^{\mathrm{b}}$ & $7.33^{\mathrm{a}}$ & $7.19^{\mathrm{a}}$ & 0.38 & 0.57 \\
$\left(\mathrm{~kg} \mathrm{ha}^{-1}\right)$ & $\mathrm{K}$ & $21.39^{\mathrm{b}}$ & $20.44^{\mathrm{b}}$ & $34.53^{\mathrm{a}}$ & $34.93^{\mathrm{a}}$ & 2.16 & 3.30 & $18.23^{\mathrm{b}}$ & $16.61^{\mathrm{b}}$ & $37.05^{\mathrm{a}}$ & $37.00^{\mathrm{a}}$ & 2.31 & 3.54 \\
\hline Total nutrients recycled & $\mathrm{N}$ & $61.64^{\mathrm{c}}$ & $42.41^{\mathrm{d}}$ & $167.17^{\mathrm{b}}$ & $189.54^{\mathrm{a}}$ & 10.68 & 16.33 & $58.75^{\mathrm{c}}$ & $41.61^{\mathrm{d}}$ & $158.66^{\mathrm{b}}$ & $183.17^{\mathrm{a}}$ & 11.59 & 17.72 \\
through plant biomass & $\mathrm{P}$ & $7.17^{\mathrm{c}}$ & $6.00^{\mathrm{c}}$ & $15.36^{\mathrm{b}}$ & $18.52^{\mathrm{a}}$ & 2.21 & 3.37 & $6.40^{\mathrm{c}}$ & $5.56^{\mathrm{c}}$ & $15.25^{\mathrm{b}}$ & $17.47^{\mathrm{a}}$ & 2.09 & 3.20 \\
(kg ha $\left.^{-1}\right)$ & $\mathrm{K}$ & $37.47^{\mathrm{b}}$ & $30.71^{\mathrm{c}}$ & $79.66^{\mathrm{a}}$ & $81.77^{\mathrm{a}}$ & 3.24 & 4.95 & $34.14^{\mathrm{c}}$ & $27.62^{\mathrm{d}}$ & $76.84^{\mathrm{b}}$ & $81.54^{\mathrm{a}}$ & 3.94 & 6.03 \\
\hline
\end{tabular}

Means with the same letter within row are not significantly different $(P<0.05)$.

T0 (control 1): one-year fallow-yam rotation; TM (control 2): maize-yam rotation; TMA: A. histrix/maize intercropping-yam rotation; TMM: $M$. pruriens/maize intercropping-yam rotation; SD: standard deviation; LSD: least square difference at $5 \%$. 
TABle 10: (a) Soil characteristics at the end of the experiment (December 2005), 0-10 and 10-20 cm layers, on 1-year fallow of Andropogon gayanus-yam rotation (T0), 32 farmers, four village sites, Benin. (b) Soil characteristics at the end of the experiment (December 2005), 0-10 and 10-20 cm layers, on maize-yam rotation (TM), 32 farmers, four village sites, Benin. (c) Soil characteristics at the end of the experiment (December 2005), 0-10 and 10-20 cm layers, on A. histrix/maize intercropping-yam rotation (TMA), 32 farmers, four village sites, Benin. (d) Soil characteristics at the end of the experiment (December 2005), 0-10 and 10-20 cm layers, on M. pruriens/maize intercropping-yam rotation (TMM), 32 farmers, four village sites, Benin. (e) Soil characteristics at the end of the experiment (December 2005), 0-10 and 10$20 \mathrm{~cm}$ layers, four yam-based cropping systems (1-year fallow of Andropogon gayanus-yam rotation; maize-yam rotation; A. histrix/maize intercropping-yam rotation; M. pruriens/maize intercropping-yam rotation), 32 farmers, four village sites, Benin (all sites confounded).

(a)

\begin{tabular}{|c|c|c|c|c|c|c|c|c|}
\hline \multirow{3}{*}{ Depth $(\mathrm{cm})$} & \multicolumn{2}{|c|}{ Akpéro } & \multicolumn{2}{|c|}{ Gbanlin } & \multicolumn{2}{|c|}{ Miniffi } & \multicolumn{2}{|c|}{ Gomè } \\
\hline & $0-10$ & $10-20$ & $0-10$ & $10-20$ & $0-10$ & $10-20$ & $0-10$ & $10-20$ \\
\hline & \multicolumn{2}{|c|}{ "Plinthosols" } & \multicolumn{2}{|c|}{ "Plinthosols" } & \multicolumn{2}{|c|}{ "Luvisols ferriques" } & \multicolumn{2}{|c|}{ "Luvisols ferriques" } \\
\hline Clay\% & 5.927 & 6.101 & 5.276 & 5.227 & 6.078 & 6.143 & 6.004 & 6.239 \\
\hline Silt $\%$ & 10.482 & 10.755 & 5.425 & 5.446 & 6.329 & 6.568 & 15.950 & 16.089 \\
\hline Sand $\%$ & 83.587 & 83.143 & 89.293 & 89.325 & 87.587 & 87.287 & 78.046 & 77.671 \\
\hline $\mathrm{C} \%$ & 0.996 & 0.909 & 0.686 & 0.672 & 0.756 & 0.723 & 0.625 & 0.587 \\
\hline N\% & 0.080 & 0.087 & 0.0575 & 0.059 & 0.061 & 0.061 & 0.0588 & 0.058 \\
\hline $\mathrm{C} / \mathrm{N}$ & 12.523 & 10.911 & 12.00 & 11.389 & 12.438 & 11.928 & 10.821 & 10.211 \\
\hline OM\% & 1.713 & 1.563 & 1.180 & 1.157 & 1.301 & 1.247 & 1.076 & 1.010 \\
\hline $\mathrm{PH}$ & 6.364 & 6.095 & 6.020 & 6.278 & 5.934 & 6.020 & 5.934 & 5.848 \\
\hline Bray P & 20.440 & 18.880 & 5.646 & 5.743 & 9.073 & 6.688 & 5.668 & 3.693 \\
\hline $\mathrm{K}$ & 0.385 & 0.366 & 0.407 & 0.283 & 0.329 & 0.214 & 0.203 & 0.201 \\
\hline
\end{tabular}

C\%: soil carbon concentration; N\%: soil nitrogen concentration; OM\% (=1.72 $\times$ C\%): soil organic matter content; C/N: index of biodegradability or ratio of soil carbon to nitrogen; Bray P (mg/kg-soil): soil phosphorus; $\mathrm{K} \mathrm{cmol} \mathrm{kg}^{-1}$ : soil potassium.

(b)

\begin{tabular}{|c|c|c|c|c|c|c|c|c|}
\hline \multirow{3}{*}{ Depth $(\mathrm{cm})$} & \multicolumn{2}{|c|}{ Akpéro } & \multicolumn{2}{|c|}{ Gbanlin } & \multicolumn{2}{|c|}{ Miniffi } & \multicolumn{2}{|c|}{ Gomè } \\
\hline & $0-10$ & $10-20$ & $0-10$ & $10-20$ & $0-10$ & $10-20$ & $0-10$ & $10-20$ \\
\hline & \multicolumn{2}{|c|}{ "Plinthosols" } & \multicolumn{2}{|c|}{ "Plinthosols" } & \multicolumn{2}{|c|}{ "Luvisols ferriques" } & \multicolumn{2}{|c|}{ "Luvisols ferriques" } \\
\hline Clay\% & 5.363 & 5.666 & 5.020 & 5.006 & 5.913 & 5.811 & 5.780 & 5.959 \\
\hline Silt $\%$ & 10.820 & 10.951 & 5.393 & 5.573 & 6.271 & 6.358 & 16.226 & 16.348 \\
\hline Sand $\%$ & 83.816 & 83.381 & 89.581 & 89.423 & 87.815 & 87.834 & 77.997 & 77.697 \\
\hline $\mathrm{C} \%$ & 1.015 & 0.9165 & 0.669 & 0.655 & 0.754 & 0.684 & 0.617 & 0.557 \\
\hline N\% & 0.089 & 0.109 & 0.066 & 0.078 & 0.075 & 0.082 & 0.072 & 0.071 \\
\hline $\mathrm{C} / \mathrm{N}$ & 11.419 & 8.575 & 10.113 & 8.520 & 10.223 & 8.355 & 8.591 & 7.786 \\
\hline OM\% & 1.746 & 1.576 & 1.150 & 1.127 & 1.297 & 1.176 & 1.062 & 0.959 \\
\hline $\mathrm{PH}$ & 6.993 & 6.733 & 6.650 & 6.897 & 6.555 & 6.650 & 6.555 & 6.441 \\
\hline Bray P & 22.610 & 21.750 & 7.031 & 7.604 & 8.041 & 6.024 & 8.041 & 6.024 \\
\hline $\mathrm{K}$ & 0.582 & 0.493 & 0.466 & 0.353 & 0.376 & 0.239 & 0.271 & 0.235 \\
\hline
\end{tabular}

C\%: soil carbon concentration; N\%: soil nitrogen concentration; OM\% $(=1.72 \times \mathrm{C} \%)$ : soil organic matter content; C/N: index of biodegradability or ratio of soil carbon to nitrogen; Bray P (mg/kg-soil): soil phosphorus; $\mathrm{K} \mathrm{cmol} \mathrm{kg}^{-1}$ : soil potassium.

(c)

\begin{tabular}{|c|c|c|c|c|c|c|c|c|}
\hline \multirow{3}{*}{ Depth (cm) } & \multicolumn{2}{|c|}{ Akpéro } & \multicolumn{2}{|c|}{ Gbanlin } & \multicolumn{2}{|c|}{ Miniffi } & \multicolumn{2}{|c|}{ Gomè } \\
\hline & $0-10$ & $10-20$ & $0-10$ & $10-20$ & $0-10$ & $10-20$ & $0-10$ & $10-20$ \\
\hline & \multicolumn{2}{|c|}{ "Plinthosols" } & \multicolumn{2}{|c|}{ "Plinthosols" } & \multicolumn{2}{|c|}{ "Luvisols ferriques" } & \multicolumn{2}{|c|}{ "Luvisols ferriques" } \\
\hline Clay\% & 6.509 & 6.752 & 5.455 & 5.999 & 6.245 & 5.882 & 5.567 & 5.390 \\
\hline Silt\% & 10.581 & 10.811 & 5.513 & 5.608 & 6.310 & 6.396 & 15.85 & 15.866 \\
\hline Sand $\%$ & 82.910 & 82.438 & 89.033 & 88.394 & 87.445 & 87.721 & 78.748 & 78.744 \\
\hline $\mathrm{C} \%$ & 1.1248 & 1.0583 & 0.732 & 0.685 & 0.781 & 0.771 & 0.635 & 0.608 \\
\hline N\% & 0.107 & 0.124 & 0.073 & 0.084 & 0.084 & 0.092 & 0.079 & 0.076 \\
\hline $\mathrm{C} / \mathrm{N}$ & 10.707 & 8.654 & 10.115 & 8.197 & 9.300 & 8.417 & 8.082 & 8.006 \\
\hline OM\% & 1.935 & 1.820 & 1.260 & 1.178 & 1.344 & 1.326 & 1.092 & 1.046 \\
\hline $\mathrm{PH}$ & 7.371 & 7.221 & 7.112 & 7.237 & 7.034 & 7.087 & 6.997 & 7.031 \\
\hline Bray P & 23.890 & 22.930 & 8.929 & 8.540 & 9.364 & 6.900 & 9.364 & 6.900 \\
\hline $\mathrm{K}$ & 0.687 & 0.604 & 0.509 & 0.436 & 0.452 & 0.297 & 0.332 & 0.298 \\
\hline
\end{tabular}

C\%: soil carbon concentration; N\%: soil nitrogen concentration; OM\% $(=1.72 \times \mathrm{C} \%)$ : soil organic matter content; C/N: index of biodegradability or ratio of soil carbon to nitrogen; Bray P (mg/kg-soil): soil phosphorus; $\mathrm{K} \mathrm{cmol} \mathrm{kg}^{-1}$ : soil potassium. 
(d)

\begin{tabular}{|c|c|c|c|c|c|c|c|c|}
\hline \multirow{3}{*}{ Depth (cm) } & \multicolumn{2}{|c|}{ Akpéro } & \multicolumn{2}{|c|}{ Gbanlin } & \multicolumn{2}{|c|}{ Miniffi } & \multicolumn{2}{|c|}{ Gomè } \\
\hline & $0-10$ & $10-20$ & $0-10$ & $10-20$ & $0-10$ & $10-20$ & $0-10$ & $10-20$ \\
\hline & \multicolumn{2}{|c|}{ "Plinthosols" } & \multicolumn{2}{|c|}{ "Plinthosols" } & \multicolumn{2}{|c|}{ "Luvisols ferriques" } & \multicolumn{2}{|c|}{ "Luvisols ferriques" } \\
\hline Clay\% & 6.180 & 6.539 & 5.724 & 6.045 & 6.371 & 6.191 & 5.561 & 5.440 \\
\hline Silt $\%$ & 10.556 & 10.789 & 5.519 & 5.579 & 6.330 & 6.373 & 15.714 & 15.841 \\
\hline Sand $\%$ & 83.264 & 82.673 & 88.758 & 88.376 & 87.299 & 87.436 & 78.725 & 78.719 \\
\hline $\mathrm{C} \%$ & 1.244 & 1.150 & 0.757 & 0.729 & 0.819 & 0.810 & 0.655 & 0.619 \\
\hline N\% & 0.127 & 0.138 & 0.083 & 0.086 & 0.088 & 0.094 & 0.085 & 0.078 \\
\hline $\mathrm{C} / \mathrm{N}$ & 9.959 & 8.425 & 9.224 & 8.545 & 9.239 & 8.457 & 7.707 & 7.944 \\
\hline OM\% & 2.140 & 1.978 & 1.303 & 1.253 & 1.409 & 1.393 & 1.126 & 1.064 \\
\hline $\mathrm{PH}$ & 7.225 & 7.162 & 6.963 & 6.912 & 6.875 & 6.975 & 7.062 & 6.888 \\
\hline Bray P & 23.110 & 22.700 & 10.015 & 10.393 & 11.665 & 7.755 & 11.665 & 7.755 \\
\hline $\mathrm{K}$ & 0.746 & 0.663 & 0.552 & 0.494 & 0.479 & 0.338 & 0.367 & 0.315 \\
\hline
\end{tabular}

C\%: soil carbon concentration; N\%: soil nitrogen concentration; OM\% $(=1.72 \times \mathrm{C} \%)$ : soil organic matter content; $\mathrm{C} / \mathrm{N}$ : index of biodegradability or ratio of soil carbon to nitrogen; Bray P (mg/kg-soil): soil phosphorus; $\mathrm{K} \mathrm{cmol} \mathrm{kg}^{-1}$ : soil potassium.

(e)

\begin{tabular}{|c|c|c|c|c|c|c|}
\hline Soil characteristics & Depth & T0 & TM & TMA & TMM & LSD \\
\hline \multirow{2}{*}{ Clay\% } & $0-10 \mathrm{~cm}$ & $5.821^{\mathrm{c}}$ & $5.519^{\mathrm{d}}$ & $5.944^{\mathrm{b}}$ & $5.959^{\mathrm{a}}$ & 0.111 \\
\hline & $10-20 \mathrm{~cm}$ & $5.928^{c}$ & $5.611^{\mathrm{d}}$ & $6.006^{\mathrm{b}}$ & $6.054^{\mathrm{a}}$ & 0.124 \\
\hline \multirow{2}{*}{ Silt\% } & $0-10 \mathrm{~cm}$ & $9.546^{\mathrm{a}}$ & $9.678^{\mathrm{a}}$ & $9.522^{\mathrm{a}}$ & $9.530^{\mathrm{a}}$ & ns \\
\hline & $10-20 \mathrm{~cm}$ & $9.714^{\mathrm{a}}$ & $9.807^{\mathrm{a}}$ & $9.670^{\mathrm{a}}$ & $9.645^{\mathrm{a}}$ & ns \\
\hline \multirow{2}{*}{ Sand $\%$} & $0-10 \mathrm{~cm}$ & $84.628^{\mathrm{a}}$ & $84.802^{\mathrm{a}}$ & $84.534^{\mathrm{a}}$ & $84.511^{\mathrm{a}}$ & ns \\
\hline & $10-20 \mathrm{~cm}$ & $84.357^{\mathrm{a}}$ & $84.584^{\mathrm{a}}$ & $84.324^{\mathrm{a}}$ & $84.301^{\mathrm{a}}$ & ns \\
\hline \multirow{2}{*}{$\mathrm{C} \%$} & $0-10 \mathrm{~cm}$ & $0.766^{\mathrm{b}}$ & $0.764^{\mathrm{b}}$ & $0.818^{\mathrm{b}}$ & $0.869^{\mathrm{a}}$ & 0.037 \\
\hline & $10-20 \mathrm{~cm}$ & $0.723^{\mathrm{b}}$ & $0.703^{\mathrm{b}}$ & $0.780^{\mathrm{a}}$ & $0.827^{\mathrm{a}}$ & 0.033 \\
\hline \multirow{2}{*}{$\mathrm{N} \%$} & $0-10 \mathrm{~cm}$ & $0.064^{\mathrm{d}}$ & $0.076^{\mathrm{c}}$ & $0.086^{\mathrm{b}}$ & $0.095^{\mathrm{a}}$ & 0.003 \\
\hline & $10-20 \mathrm{~cm}$ & $0.066^{\mathrm{c}}$ & $0.085^{\mathrm{b}}$ & $0.094^{\mathrm{a}}$ & $0.099^{\mathrm{a}}$ & 0.004 \\
\hline \multirow{2}{*}{$\mathrm{C}: \mathrm{N}$} & $0-10 \mathrm{~cm}$ & $11.947^{\mathrm{a}}$ & $10.087^{b}$ & $9.551^{c}$ & $9.032^{c}$ & 0.272 \\
\hline & $10-20 \mathrm{~cm}$ & $11.109^{\mathrm{a}}$ & $8.309^{\mathrm{b}}$ & $8.319^{\mathrm{b}}$ & $8.343^{\mathrm{b}}$ & 0.211 \\
\hline \multirow{2}{*}{$\mathrm{MO} \%$} & $0-10 \mathrm{~cm}$ & $1.317^{\mathrm{b}}$ & $1.313^{\mathrm{b}}$ & $1.408^{\mathrm{a}}$ & $1.495^{\mathrm{a}}$ & 0.063 \\
\hline & $10-20 \mathrm{~cm}$ & $1.244^{\mathrm{c}}$ & $1.209^{\mathrm{c}}$ & $1.342^{\mathrm{b}}$ & $1.422^{\mathrm{a}}$ & 0.057 \\
\hline \multirow{2}{*}{ Bray P $\left(\mathrm{mg} \mathrm{kg}^{-1}\right)$} & $0-10 \mathrm{~cm}$ & $10.210^{c}$ & $11.840^{\mathrm{b}}$ & $13.430^{\mathrm{a}}$ & $14.346^{\mathrm{a}}$ & 1.126 \\
\hline & $10-20 \mathrm{~cm}$ & $8.750^{\mathrm{c}}$ & $10.660^{\mathrm{b}}$ & $11.410^{\mathrm{ab}}$ & $12.290^{\mathrm{a}}$ & 1.217 \\
\hline \multirow{2}{*}{$\mathrm{K}^{+} \mathrm{cmol} \mathrm{kg}^{-1}$} & $0-10 \mathrm{~cm}$ & $0.331^{\mathrm{d}}$ & $0.424^{\mathrm{c}}$ & $0.495^{\mathrm{b}}$ & $0.536^{\mathrm{a}}$ & 0.026 \\
\hline & $10-20 \mathrm{~cm}$ & $0.266^{\mathrm{d}}$ & $0.330^{\mathrm{c}}$ & $0.409^{\mathrm{b}}$ & $0.453^{\mathrm{a}}$ & 0.028 \\
\hline \multirow{2}{*}{$\mathrm{PH}$ water } & $0-10 \mathrm{~cm}$ & $6.063^{c}$ & $6.688^{\mathrm{b}}$ & $7.129^{a}$ & $7.031^{\mathrm{a}}$ & 0.055 \\
\hline & $10-20 \mathrm{~cm}$ & $6.060^{\mathrm{c}}$ & $6.680^{\mathrm{b}}$ & $7.144^{\mathrm{a}}$ & $6.984^{\mathrm{a}}$ & 0.053 \\
\hline
\end{tabular}

Means with the same letter within row are not significantly different $(P>0.05)$.

C\%: soil carbon concentration; N\%: soil nitrogen concentration; OM\% $(=1.72 \times \mathrm{C} \%)$ : soil organic matter content; $\mathrm{C}: \mathrm{N}$ : ratio of soil carbon to nitrogen; Bray $\mathrm{P}$ (mg/kg-soil): soil phosphorus; $\mathrm{K}^{+} \mathrm{cmol} \mathrm{kg}^{-1}$ : soil potassium; LSD: least square difference at 5\%; SD: standard deviation.

T0 (control 1): one-year fallow-yam rotation; TM (control 2): maize-yam rotation; TMA: A. histrix/maize intercropping-yam rotation; TMM: M. pruriens/maize intercropping-yam rotation; LSD: least square difference at 5\%; ns: nonsignificant.

Data are the means.

effect of cropping sequences with cassava and legume crops, [36] indicated that only $30 \%$ of $M$. pruriens litter remained six weeks after incorporation of the biomass. References [37] and [38] that studied the traditional $M$. pruriens-maize rotation in Honduras estimated that $83 \%$ of nitrogen produced by a mulch of $M$. pruriens was available for the following maize crop. They also observed that available $\mathrm{P}$ remained practically constant, with 15 to $20 \mathrm{mg} / \mathrm{kg}$-soil in the surface horizon in spite of P exports by maize. Reference [38] concluded that the practice of continued rotation with $M$. pruriens and maize prevented soil $\mathrm{N}$ depletion for at least 15 years.
Our results showed that legumes improved soil $\mathrm{P}$. Legumes fallows with $M$. pruriens are known especially for improving the quantity of available $\mathrm{P}$ fractions in the soil for subsequent crops [39]. Nevertheless, they depend on the inherent P levels in the soils. M. pruriens root exudates could solubilize P increasing its availability. In the study of [40], organic materials have also been found to reduce $\mathrm{P}$ sorption capacity of soils and increase crop yields in P limiting soils.

The soil $\mathrm{K}$ concentrations were improved in our study (Table 4). Reference [3] showed soil $\mathrm{K}$ concentration of $0.82 \mathrm{cmol} \mathrm{kg}^{-1}$ in the $0-20 \mathrm{~cm}$ soil layer and decreasing 
significantly with cultivation. The rate of decline was about $0.023-0.054 \mathrm{cmol} \mathrm{kg}^{-1}$ year $^{-1}$ in the $0-20 \mathrm{~cm}$ soil layer [3].

\section{Conclusions}

The field of interest of the study is to determine the impact of yam-based systems with herbaceous legumes on dry matter production (tubers and shoots), nutrients removed and recycled, and the soil fertility changes. Yam tuber dry matter production was significantly improved in yambased systems with legumes in comparison with traditional systems. Treatment $\times$ Farmer and Year $\times$ Treatment interactions influenced significantly the yam tuber dry matter production. Amounts of N, P, and $\mathrm{K}$ recycled in yam shoot were significantly higher in yam-based systems with legumes than in traditional systems. The nutrient $(\mathrm{N}, \mathrm{P}$, and $\mathrm{K})$ levels removed or recycled fit the DM production (tubers and shoots) and then varied according to treatments and cropping seasons. The end of study soil analysis showed soil chemical properties (SOM\%, N\%, P (mg/kg-soil), $\mathrm{K}^{+} \mathrm{cmol} / \mathrm{kg}$, and $\mathrm{pH}$ water) significantly higher in treatments with legumes than in traditional systems. We then propose to promote durable and replicable yam-based systems with legumes, through a favorable legislative, economic, and political environment to support local initiatives. Collaborations between farmers, research, development, and extension structures should also be favored to support the development and dissemination of innovations.

\section{Competing Interests}

The authors declare that there is no conflict of interests regarding the publication of this paper.

\section{Acknowledgments}

The authors express their sincere appreciation and thanks for the Cooperation Program for Academic and Scientific Research (CORUS). Finally, the authors greatest appreciation goes to farmers who freely agreed to participate in trials and make part of their fields available for the research.

\section{References}

[1] FAO (Food and Agriculture Organization), "FAO-UNESCO soil map of the world. Revised legend," Soils Bulletin 60, FAO, Rome, Italy, 1990.

[2] A. H. Azontonde, "Dégradation et restauration des terres de barre (sols ferrallitiques faiblement désaturés argilo-sableux) au Bénin. La gestion conservatoire de l'eau, de la biomasse et de la fertilité des sols (GCES)," cah. Orstom, Ser. Pedol, vol. 28, no. 2, pp. 217-226, 1993.

[3] A. M. Igué, The use of the soil database for land evaluation procedures-case study of central Benin [Ph.D. thesis], University of Hohenheim, Stuttgart, Germany, 2000.

[4] D. Cornet, P. Vernier, F. Amadji, and R. Asiedu, "Integration of yam in cover crop based cropping system: constraints and potential," in Proceedings of the 14th Triennial Symposium of the International Society for Tropical Root Crops (ISTRC '06), Central Tuber Crops Research Institute, Thiruvananthapuram, India, 2006.
[5] L. Herrmann, Staubdeposition auf Böden West Africas. Eigenschaften und Herkunftsgebiete der Stä̈ube und ihr Einfluß auf Böden und Standortseigenschaften. Hohenheimer Bodenk, Hefte 36, Hohenheim University, Stuttgart, Germany, 1996.

[6] T. Gaiser, B. Fadegnon, M. Cretenet, and C. Gaborel, "Longterm experience on a tropical Acrisol: evolution of soil properties and yield," UFZ—Berichte, vol. 24, pp. 153-156, 1999.

[7] S. Hauser, "Biomass production, nutrient uptake and partitioning in planted Senna spectabilis, Flemingia macrophylla, and Dactyladenia barteri fallow systems over three fallow/cropping cycles on Ultisol," in Paper Presented at Tropentag, Bonn, Germany, October 2006.

[8] J. Gockowsky, J. Tonye, D. Baker et al., ASB Report Phase II. March 1999, IITA/IRAD, Yaoundé, Cameroon, 2002.

[9] I. C. Onwueme and A. J. Haverkort, "Modelling growth and productivity of Yams (Dioscorea Spp): prospects and problems," Agricultural Systems, vol. 36, no. 3, pp. 351-367, 1991.

[10] FAO, FAOSTAT Crop Production Data, 2009, http://faostat.fao .org/.

[11] R. J. Carsky, M. Becker, and S. Hauser, "Mucuna cover crop fallow systems: potential and limitations," in Sustaining Soil Fertility in West Africa, G. Tian, F. Ishida, and J. D. H. Keatinge, Eds., vol. 58 of SSSA Special Publication, pp. 111-135, Soil Science Society of America and American Society of Agronomy, Madison, Wis, USA, 2001.

[12] P. Vernier and R. A. Dossou, "Adaptation of yam (Dioscorea spp) cultivation to changing environment and economic constraints in Benin, Africa," in Proceedings of the 12th Symposium of the International Society for Tropical Root Crops (ISTRC '00), pp. 352-359, Tsukuba, Japan, September 2000.

[13] S. Doumbia, "Revue de la bibliographie sur le thème de la sédentarisation de la culture de l'igname en Afrique de l'Ouest à travers le cas du Bénin," FAO/MAEP/INRAB, 2005.

[14] R. Maliki, Sédentarisation de la culture d'igname et gestion durable des ressources naturelles dans la région centre du Bénin: développement participatif, contraintes, adoption et diffusion des technologies [Thèse DEA], University of Abomey-Calavi (UAC), Abomey-Calavi, Benin, 2006.

[15] A. Saïdou, Converging strategies by farmers and scientist to improve soil fertility and enhance crop production in Benin [Ph.D. thesis], Wageningen University, Wageningen, The Netherlands, 2006.

[16] J. N. O'Sullivan and J. Ernest, Yam Nutrition and Soil Fertility Management in the Pacific, ACIAR, Canberra, Australia, 2008.

[17] R. J. Carsky, S. A. Tarawali, M. Becker, D. Chicoye, G. Tian, and N. Sanginga, Mucuna: A Herbaceous Cover Legume with Potential for Multiple Use, vol. 25 of Resource and Crop Management Division (RCMD). Research Monographs, International Institute of Tropical Agriculture, Ibadan, Nigeria, 1998.

[18] M. Becker, D. E. Johnson, and Z. J. Segda, "The role of legume fallows in intensified unpland rice-based systems of West Africa," in Cover Crops in West Africa. Contributing to Sustainable Agriculture, D. Buckles, A. Etèka, O. Osiname, M. Galiba, and G. Galiano, Eds., pp. 85-108, International Development Research Centre, International Institute of Tropical Agriculture, Sasakawa Global 2000, Cotonou, Benin, 1999.

[19] D. Dubrouecq, Etude des Sols de la Région Ouest Dassa-Zoumè, vol. 96 of Etude, CENAP, Bénin, 1977.

[20] V. Agossou and M. Igué, Caractérisation des Sols des Sites de Recherche Développement du Cra-Centre: Classification Dans la Base de Référence Mondiale et Actualisation de Leur Niveau 
de Dégradation, CRA- Centre, INRAB/MAEP, Savè, Bénin, 1st edition, 2002.

[21] P. Vernier and R. A. Dossou, "An example of sedentarization of yam cultivation. The case of Kokoro varieties in the Republic of Benin," Agronomie Africaine, vol. 15, no. 4, pp. 187-196, 2003, Atelier national sur le développement durable de la production et de la consommation de l'igname en Côte d'Ivoire, 2001-1023/2001-10-26, Abidjan, Côte d'Ivoire.

[22] H. Scarf, "One hundred years of the Kjeldahl method for nitrogen determination," Archiv für Acker- und Pflanzenbau und Bodenkunde, vol. 32, pp. 321-332, 1988.

[23] R. H. Bray, "A nutrient mobility concept of soil-plant relationships," Soil Science, vol. 78, no. 1, pp. 9-22, 1954.

[24] FAO, A Standard Guide to Soil Fertility Investigations in Faners' Fields, Soils Bulletin no. 11, FAO, Rome, Italy, 1970.

[25] FAO, Soil and Plant Testing and Analysis, Soils Bulletin no. 38/1, FAO, Rome, Italy, 1977.

[26] A. Walkley and I. A. Black, "An examination of the Degtjareff method for determining soil organic matter, and a proposed modification of the chromic acid titration method," Soil Science, vol. 37, no. 1, pp. 29-38, 1934.

[27] G. W. Robinson, Soils, Their Origin, Constitution and Classification, Thomas Murby \& Co, London, UK, 2nd edition, 1936.

[28] SAS Institute, SAS User's Guide: Statistics, SAS Institute, Cary, NC, USA, 1996.

[29] R. Lal, "Tillage and mulching effects on maize yield for seventeen consecutive seasons on a tropical Alfisol," Journal of Sustainable Agriculture, vol. 5, no. 4, pp. 79-93, 1995.

[30] R. Maliki, M. Toukourou, F. Amadji, and I. Adjé, "Référentiel technico-économique sur la production durable de l'igname de qualité dans un système de cultures intégrant l'Aeschynomene histrix," Tech. Rep. FAO/TCP/BEN/3002 (A), INRAB/MAEP, Cotonou, Bénin, 2007.

[31] R. Maliki, M. Toukourou, F. Amadji, and I. Adjé, Référentiel Technico-Économique sur la Production Durable de l'Igname de Qualité Dans un Système de Cultures Intégrant le Mucuna pruriens var utilis, FAO/TCP/BEN/3002 (A), INRAB/MAEP, Cotonou, Bénin, 2007.

[32] L. Degras, "The yam: a tropical root crop," in Agricultural Technic and Tropical Production, Maisonneuve and Larose, Paris, France, 1986.

[33] M. Quenum, M. Giroux, and R. Royer, "Étude sur le bilan humique des sols dans des systèmes culturaux sous prairies et sous cultures commerciales selon les modes de fertilization," Agrosol, vol. 15, no. 2, pp. 57-71, 2004.

[34] French Ministry of Cooperation, Memento de l'Agronome, French Ministry of Cooperation, 1993.

[35] M. A. Bolinder, Contribution aux connaissances de la dynamique du C dans les systèmes SOL-PLANTE de l'Est du Canada [Ph.D. thesis], Université Laval, 2003.

[36] S. Adjei-Nsiah, T. W. Kuyper, C. Leeuwis, M. K. Abekoe, and K. E. Giller, "Evaluating sustainable and profitable cropping sequences with cassava and four legume crops: effects on soil fertility and maize yields in the forest/savannah transitional agro-ecological zone of Ghana," Field Crops Research, vol. 103, no. 2, pp. 87-97, 2007.

[37] M. van Noordwijk, T. P. Tomich, R. Winahyu, D. Murdiyarso, S. Partoharjono, and A. M. Fagi, Eds., Alternatives to Slash-andBurn in Indonesia: Summary Report of Phase 1. Alternatives to Slash-and-Burn Agriculture (ASB)-Indonesia Report No. 4, ASBIndonesia Consortium and ICRAF, Bogor, Indonesia, 1995.
[38] B. L. Triomphe, Seasonal nitrogen dynamics and long-term changes in soil properties under the Mucuna/maize cropping system on the hillsides of northern Honduras [Ph.D. dissertation], Cornell University, Ithaca, NY, USA, 1996.

[39] F. K. Salako and G. Tian, "Management of a degraded Alfisol for crop production in southwestern Nigeria: effects of fallow, mounding and nitrogen," Journal of Sustainable Agriculture, vol. 22, no. 2, pp. 3-22, 2003.

[40] G. Nziguheba, C. A. Palm, R. J. Buresh, and P. C. Smithson, "Soil phosphorus fractions and adsorption as affected by organic and inorganic sources," Plant and Soil, vol. 198, no. 2, pp. 159-168, 1998. 


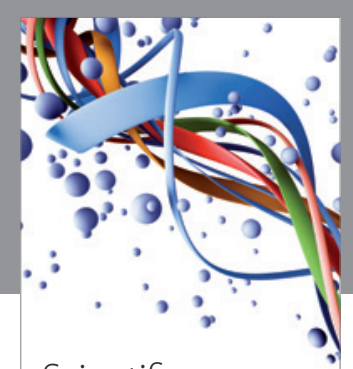

Scientifica
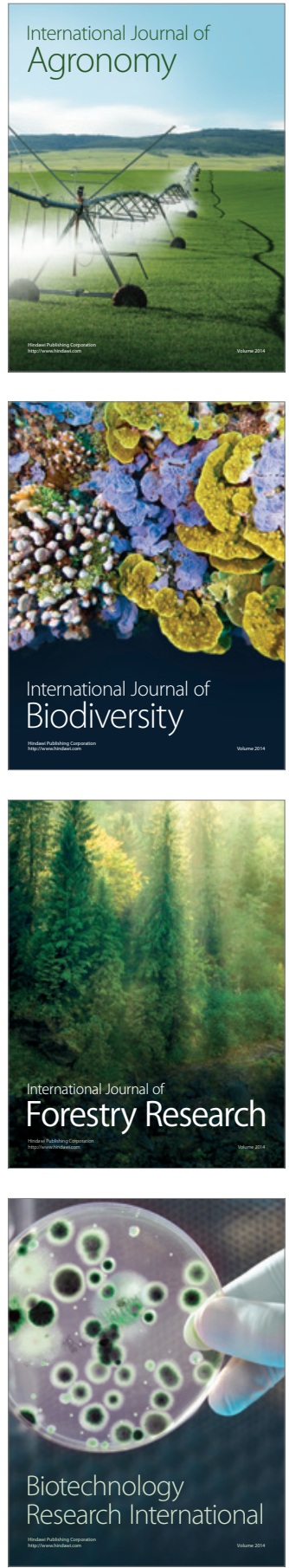
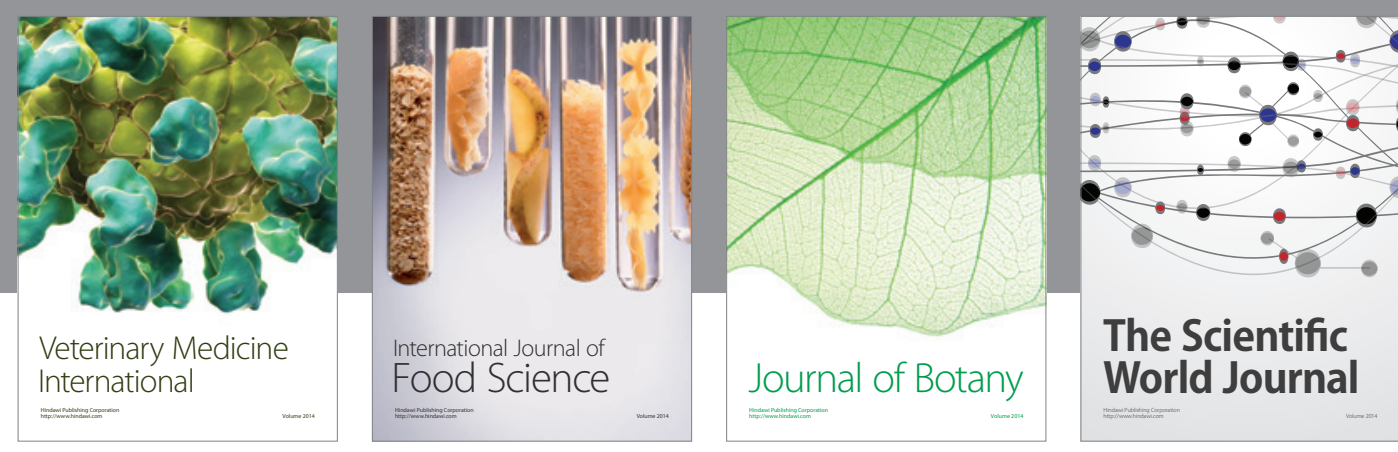

The Scientific

\section{World Journal}

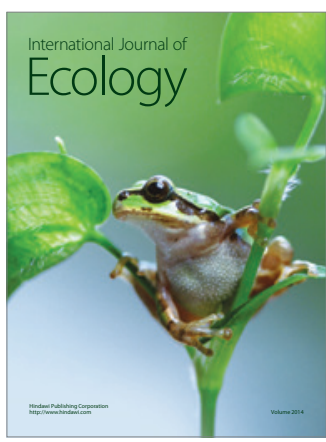

\section{Hindawi}

Submit your manuscripts at

http://www.hindawi.com
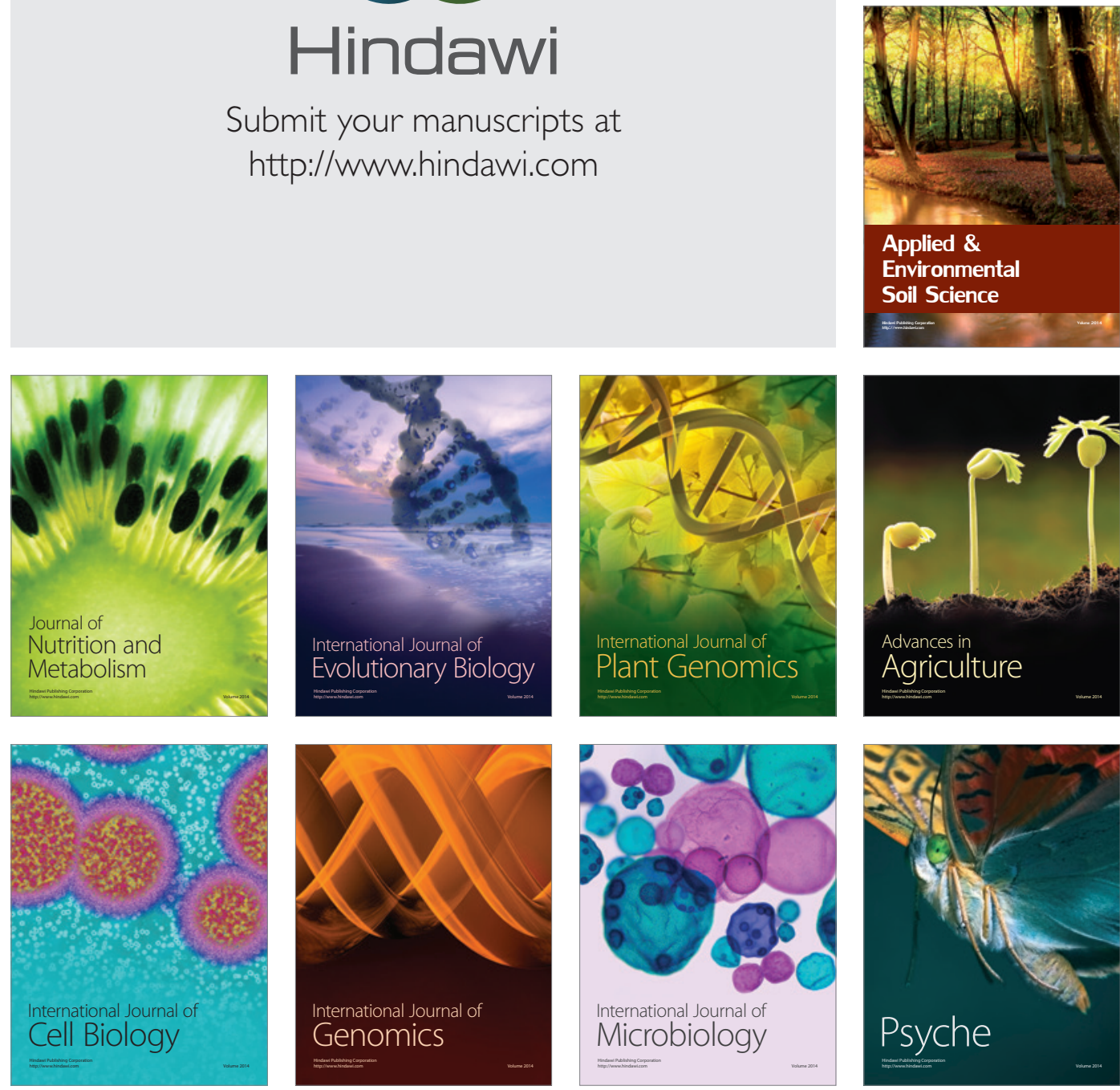
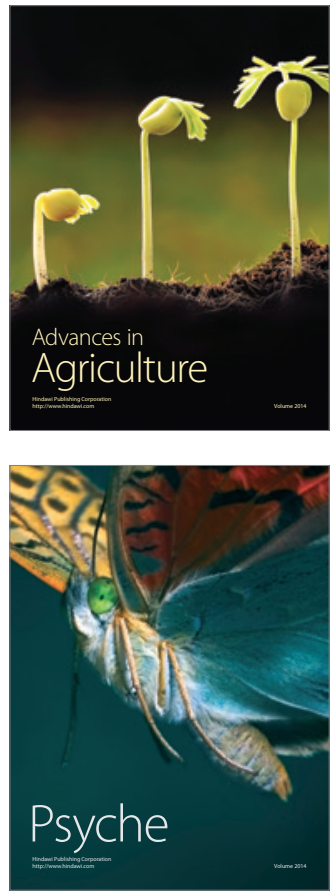